\title{
One-year outcome in patients with idiopathic normal-pressure hydrocephalus treated with a lumbo-peritoneal shunt (SINPHONI-2), compared to ventriculo-peritoneal shunt (SINPHONI) used as a historical control
}

\author{
Masakazu Miyajima ${ }^{1 *}$, Hiroaki Kazui ${ }^{2}$, Etsuro Mori ${ }^{3}$, Masatsune Ishikawa ${ }^{4}$ \\ From Hydrocephalus 2015 \\ Banff, Canada. 18-21 September 2015
}

\section{Introduction}

Idiopathic normal pressure hydrocephalus (INPH) is treated with cerebrospinal fluid shunting, and ventriculoperitoneal shunt (VPS) is the current standard treatment. The goal of this pooled analysis was to compare the efficacy and safety between VPS and lumbo-peritoneal shunt (LPS) in patients with INPH specified as disproportionately enlarged subarachnoid space hydrocephalus (DESH).

\section{Methods}

We conducted a multicenter prospective 3-month randomized controlled trial, and then a 1-year extension study, where all subjects received an LPS with a programmable valve and were examined periodically for 1 year. Eightythree patients with INPH (60 to 85 years old) presenting with ventriculomegaly, high-convexity and medial subarachnoid space tightness in magnetic resonance imaging were recruited from 20 neurological or neurosurgical centers in Japan between March 1, 2010 and October 19, 2011. The primary outcome was the modified Rankin scale (mRS) score 1 year after surgery, and secondary outcome included the NPH grading scale (NPHGS). The VPS SINPHONI study was used as a historical control.

\section{Results}

The proportion of patients with a favorable outcome (i.e., improvement of at least one level in mRS) was 63\% (95\%

\footnotetext{
* Correspondence: mmasaka@juntendo.ac.jp

'Department of Neurosurgery, Juntendo University Graduate School of Medicine, Japan

Full list of author information is available at the end of the article
}

CI: 51-73\%), and was comparable to that with VPS implantation (69\%, 95\% CI: 59-78\%). In NPHGS, the one-year improvement rate was $75 \%$ (95\% CI: $64-84 \%)$ and was comparable to that of VPS (77\%, 95\% CI: 68$84 \%)$. Serious adverse events (SAEs) occurred in 19 patients (22\%), 10 of which were related to surgery. SAEs were more common with LPS than with VPS (15\%).

\section{Conclusion}

Our results show that LPSs with programmable valves are effective for treating INPH as an alternative to VPSs.

\section{Authors' details \\ 'Department of Neurosurgery, Juntendo University Graduate School of Medicine, Japan. ${ }^{2}$ Department of Psychiatry, Osaka University Graduate School of Medicine, Japan. ${ }^{3}$ Department of Behavioral Neurology and Cognitive Neuroscience, Tohoku University Graduate School of Medicine, Japan. ${ }^{4}$ Normal-Pressure Hydrocephalus Centre, Otowa Hospital, Japan.}

Published: 18 September 2015

\section{References}

1. Miyajima M, Nakajima M, Ogino I, Miyata H, Motoi Y, Arai H: Soluble amyloid precursor protein $a$ in the cerebrospinal fluid as a diagnostic and prognostic biomarker for idiopathic normal pressure hydrocephalus. Eur J Neurol 2013, 20(2):236-242.

2. Watanabe M, Miyajima M, Ogino I, Nakajima M, Arai H: Cerebellar Purkinje Cells Exhibit Increased Expression of HMGB-1 and Apoptosis in Congenital Hydrocephalic H-Tx Rats. Neurosurgery 2013, 72(3):459-467.

3. Miyajima M, Nakajima M, Motoi $Y$, Moriya M, Sugano H, Ogino I, Nakamura E, Tada N, Kunichika M, Arai H: Leucine-rich a2-glycoprotein is a novel biomarker of neurodegenerative disease in human cerebrospinal fluid and causes neurodegeneration in mouse cerebral cortex. PLOS One 2013, 8(9):e74453.

4. Hoshi K, Kariya Y, Nara K, Ito H, Matsumoto K, Nagae M, Yamaguchi Y, Nakajima M, Miyajima M, Arai H, Kuno A, Narimatsu H, Shirotani K, 
Hashimoto Y: Lectin-dependent inhibition of antigen-antibody reaction: application for measuring a2,6-sialylated glycoforms of transferrin. J Biochem 2013, 154(3):229-32.

5. Tsutsumi S, Ogino I, Miyajima M, Ikeda T, Shindo N, Yasumoto Y, Ito M, Arai $\mathrm{H}:$ Genomic causes of multiple cerebral cavernous malformations in a Japanese population. J Clin Neurosci 2013, 20(5):667-9.

6. Shimoji K, Kimura T, Kondo A, Tange Y, Miyajima M, Arai H: Genetic studies of myelomeningocele. Childs Nerv Syst 2013, 29(9):1417-25.

7. Nakanishi A, Fukunaga I, Hori M, Masutani Y, Takaaki H, Miyajima M, Aoki S: Microstructural changes of the corticospinal tract in idiopathic normal pressure hydrocephalus: a comparison of diffusion tensor and diffusional kurtosis imaging. Neuroradiology 2013, 55(8):971-6.

8. Nakajima M, Sugano H, limura Y, Higo T, Nakanishi H, Shimoji K, Karagiozov K, Miyajima M, Arai H: Sturge-Weber syndrome with spontaneous intracerebral hemorrhage in childhood. I Neurosurg Pediatr 2014, 13(1):90-3

9. Kamiya K, Hori M, Miyajima M, Nakajima M, Suzuki Y, Kamagata K, Suzuki M, Arai H, Ohtomo K, Aoki S: Axon diameter and intra-axonal volume fraction of the corticospinal tract in idiopathic normal pressure hydrocephalus measured by q-space imaging. PLoS One 2014, 9(8): e103842.

10. Tsutsumi S, Ogino I, Miyajima M, Nakamura M, Yasumoto $Y$, Arai H, Ito M: Cranial Arachnoid Protrusions and Contiguous Diploic Veins in CSF Drainage. AJNR Am J Neuroradiol 2014, 35(9):1735-9.

doi:10.1186/2045-8118-12-S1-046

Cite this article as: Miyajima et al:: One-year outcome in patients with idiopathic normal-pressure hydrocephalus treated with a lumboperitoneal shunt (SINPHONI-2), compared to ventriculo-peritoneal shunt (SINPHONI) used as a historical control. Fluids and Barriers of the CNS

2015 12(Suppl 1):046.

\section{Submit your next manuscript to BioMed Central and take full advantage of:}

- Convenient online submission

- Thorough peer review

- No space constraints or color figure charges

- Immediate publication on acceptance

- Inclusion in PubMed, CAS, Scopus and Google Scholar

- Research which is freely available for redistribution

Submit your manuscript at www.biomedcentral.com/submit 